\title{
A tentative useful-for-all definition of "safety" in the context of radioactive waste disposal
}

\author{
Stephan Hotzel \\ Federal Office for the Safety of Nuclear Waste Management (BASE), \\ Wegelystrasse 8, 10623 Berlin, Germany \\ Correspondence: Stephan Hotzel (stephan.hotzel@bfe.bund.de) \\ Published: 10 November 2021
}

\begin{abstract}
Most, if not all, national programmes for radioactive waste management pledge their overall commitment to safety or - in the case of radioactive waste disposal - to long-term safety. Therefore, it may be somewhat surprising to find that the term "safety" is hardly defined in these programs. The same holds for some of the core international guidance literature on the deep geological repository (DGR) "safety case" concept. With respect to stakeholder concern over the safety of geological disposal, it seems, however, advisable to seek common ground in the understanding of the idea of "safety". Hotzel and Schröder (2018) reviewed the most relevant international guidance literature for explicitly or implicitly provided definitions of "safety" in the context of radioactive waste disposal. Based on this study - and on the finding that a practical, useful-for-all definition of "safety" is not provided in the scanned literature - they developed a tentative dictionary-style definition of "safety" that is suitable for everyday use in the DGR context.

In the current contribution I embed, expand and update the 2018 study at both ends: As an enhanced introduction to the 2018 study, I lay out a basic concept of "sound" glossary definitions, namely glossary definitions being both practical and correct (and what this means). The thesis is that sound glossary definitions can facilitate mutual understanding between different stakeholder groups.

As an update to the actual proposal for the definition of "safety" from the Hotzel and Schröder (2018) paper, that was presented and discussed at the Waste Management Conference 2018, I review the latest international guidance literature and the stakeholder concerns raised at the 2018 conference in order to present a revised definition. As a seed of discussion, it may help to eventually expose possible mismatches in the base assumptions of safety experts and other stakeholders and thereby support meaningful communication.
\end{abstract}

Kurzfassung. Die meisten nationalen Programme für den Umgang mit radioaktiven Abfällen, wenn nicht gar alle, verpflichten sich umfassend zur Sicherheit oder - im Fall der Endlagerung radioaktiver Abfälle - zur Langzeitsicherheit. Es mag daher etwas überraschen, dass der Begriff Sicherheit in diesen Programmen selten definiert wird. Dies gilt auch für einige der wichtigsten internationalen Leitfäden zum Sicherheitskonzept (Safety Case) für geologische Endlager (deep geological repositories, DGR). Mit Blick auf die Bedenken von Interessengruppen in Hinblick auf die Sicherheit der geologischen Endlagerung scheint es jedoch ratsam, eine gemeinsame Grundlage für das Verständnis des Konzepts Sicherheit zu finden. Hotzel und Schröder (2018) haben die wichtigsten internationalen Richtlinien auf explizite oder implizite Definitionen von Sicherheit im Zusammenhang mit der Endlagerung radioaktiver Abfälle durchgesehen. Auf Grundlage dieser Untersuchung und auf Grundlage des Ergebnisses, dass eine praktikable, allseits anwendbare Definition von Sicherheit in der betrachteten Literatur nicht zu finden ist, haben sie eine vorläufige wörterbuchartige Definition von Sicherheit entwickelt, die für den Alltagsgebrauch im DGR-Kontext geeignet ist.

Im vorliegenden Beitrag ordne ich die Studie von 2018 ein und erweitere und aktualisiere sie in zwei Richtungen: Als erweiterte Einführung in die Studie von 2018 stelle ich ein grundlegendes Konzept von „klaren“ Glossardefinitionen vor, nämlich dass diese sowohl zweckmäßig als auch korrekt sein sollten (und was damit gemeint ist). Die These lautet, dass klare Glossardefinitionen das gegenseitige Verständnis zwischen den verschiedenen Interessengruppen erleichtern können. 
In einer Aktualisierung des Definitionsvorschlags für Sicherheit aus dem Konferenzbeitrag zur „Waste Management"-Konferenz von Hotzel und Schröder (2018) arbeitete ich die neuesten internationalen Richtlinien und die Bedenken der Interessengruppen, die gegenüber dem Definitionsvorschlag auf der Konferenz von 2018 geäußert wurden, auf und stelle eine entsprechend überarbeitete Definition vor. Diese mag als Denkanstoß dazu beitragen, mögliche unterschiedliche Grundannahmen von Sicherheitsexperten und anderen Interessengruppen aufzudecken und auf diese Weise eine zielführende Kommunikation zu unterstützen.

\section{References}

Hotzel, S. and Schröder, J.: To the "Safety related?" Question: What is Related to Safety? - 18430, in: Proceedings of the Waste Management Conference, Phoenix, USA, 18-22 March 2018, https://www.xcdsystem.com/wmsym/2018/ pdfs/FinalPaper_18430_0321010427.pdf (last access: 3 November 2021), 2018. 